\title{
Locomotor training as part of a rehabilitation programme for patients with spinal cord injury - a case study
}

\author{
B M Parr (MSc(Med) Exercise Science) \\ R Gamieldien (BTech (Sport Management)) \\ S E H Davies (D Phil (Human Movement Science), M ErgS (Ergonomics)
}

Cape Peninsula University of Technology

\section{Introduction}

Locomotor training for patients with spinal cord injuries has been investigated in the USA and Europe. ${ }^{2,9}$ It is a relatively new form of rehabilitation in South Africa and to our knowledge no studies have been reported on its use in this country.

This is a case study of a 24-year-old male diagnosed on 8 September 2006 with a 66 motor complete but sensory incomplete spinal cord injury (SCI). On 11 September 2006 a C7 vertebrectomy, bone graft, anterior fusion and internal fixation was performed. From 18 September to 19 December he received inpatient therapy for mobility and self-care skills. On discharge he remained sensory incomplete but some motor function had returned in the right ankle. On 22 February 2007 locomotor training began. The patient was hoisted in an alpine climbing harness (Black Diamond, USA) attached to an overhead tripod frame placed above a treadmill. Assisted walking began with two therapists manually moving the legs at $0.4 \mathrm{~km} \cdot \mathrm{h}^{-1}$. In order for the stepping to be consistent a metronome was used. Initially the patient could complete a total of 3 minutes 20 seconds of walking in two bouts of 1 minute and 2 minute 20 seconds respectively, at a speed of $0.4 \mathrm{~km} \cdot \mathrm{h}^{-1}$. The patient could not stand up with the aid of a walking frame. Strength in the quadricep and hamstring muscles was measured bilaterally on the Biodex isokinetic dynamometer (Biodex Medial Systems, New York) in passive mode. Peak torque was measured at a speed of $5^{\circ} . \mathrm{s}^{-1}$ before and after 1 year of therapy (Table I). Locomotor training was performed 5 days per week as part of an exercise routine. The exercise routine also consisted of upper body cycle ergometry, mat exercises, core stability strengthening and upper body strength training. The entire therapy regimen and progression can be seen in Table II.

\section{CORRESPONDENCE:}

Bridget Marianne Parr

Cape Peninsula University of Technology

Barklay Davies Building

Highbury Road

Mowbray 7700

Tel: 021-680-1573

Fax: 021-680-1562

Cell: 0846857294

E-mail: parrb@cput.ac.za
During the year, for 4 weeks, intermittently, exercise sessions were not attended, either due to the patient being ill or the centre being closed. After 1 year the subject completed 10 minutes of assisted walking without rest and 20 minutes of assisted walking altogether. Furthermore, the subject could walk 8 metres continuously with modified crutches.

\section{Discussion}

The conventional approach to rehabilitation in patients with spinal cord injury has been to adapt the environment to the patient. This is known as the 'compensatory model' and presupposes that the spinal cord is not malleable and capable of recovery. ${ }^{2}$ In contrast, the 'recovery model' is based on the premise that the spinal cord is malleable and capable of recovery. ${ }^{2}$ In the USA complete spinal transection (T12 - T13) was performed in adult cats. ${ }^{8}$ This caused complete loss of locomotor function in the hindlegs. The injured cats underwent training which consisted of walking on a treadmill for 30 minutes per day, 5 days per week for 5 - 7 months with therapists manually assisting their hindlegs. Five out of the 8 trained cats improved sufficiently to locomote (bearing their full body weight) for $10-20$ minutes. $^{8}$ A study using rats has also demonstrated the ability of the spinal cord to respond to stimuli without contact with the cerebellum. ${ }^{3}$ These studies demonstrate that the spinal cord has a significant level of plasticity in mammals.

Behrman et al. (2006) reviewed the studies on locomotor training and the injured human spine. ${ }^{2}$ Most have been case studies or studies with no control group and therefore their results have limited interpretability. There has only been one randomised clinical trial in this population group. ${ }^{6}$ This was a multicentre trial and found no difference in FIM-L scores (a walking ability score) and walking speeds between a locomotor training group and an overground mobility control group. FIM-L score and walking speed were the primary outcome measures but walking distance was not reported.

It is important to note that locomotor training cannot be done in an ad hoc manner. Afferent input to the spinal cord during locomotor training is important in order for training to be effective. ${ }^{2}$ Afferent input includes hip extension position during the transition from stance to swing phase (the hip should be in extension), heel strike and load on the lower limb. ${ }^{5,2}$ Maximal load should be taken on the lower extremities with minimal load on the upper extremities. ${ }^{4}$ Increased upper extremity weight bearing resulted in decreased EMG activity in the lower limbs. ${ }^{4}$ 
TABLE I. Strength (torque N.m) of the quadricep and hamstring muscles of the right and left leg before ( 4.5 months after injury) and after 1 year of training (16.5 months after injury)

\begin{tabular}{|c|c|c|c|c|c|c|c|}
\hline \multicolumn{4}{|c|}{ Peak extension torque (N.m) } & \multicolumn{4}{|c|}{ Peak flexion torque (N.m) } \\
\hline \multicolumn{2}{|c|}{ Right leg } & \multicolumn{2}{|c|}{ Left leg } & \multicolumn{2}{|c|}{ Right leg } & \multicolumn{2}{|c|}{ Left leg } \\
\hline Before & After & Before & After & Before & After & Before & After \\
\hline 17.4 & 23.9 & 16.9 & 23.8 & 18.7 & 48.8 & 16.6 & 41.5 \\
\hline
\end{tabular}

\begin{tabular}{|c|c|c|c|c|}
\hline Mode & 0 - 3 months & 3 - 6 months & $6-12$ months & Times per week \\
\hline \multicolumn{5}{|l|}{ Exercise routine } \\
\hline Locomotor training & 4 bouts of 4 minutes & 2 bouts of 8 minutes & 2 bouts of 10 minutes & 5 \\
\hline Overland walking & $\begin{array}{l}\text { After } 4 \text { weeks used walking } \\
\text { frame for } 1 \text { bout of } 8 \text { metres }\end{array}$ & $\begin{array}{l}\text { After } 4 \text { months used parallel } \\
\text { bars for } 4 \text { bouts of } 6 \text { metres }\end{array}$ & $\begin{array}{l}6 \text { - } 9 \text { months walked on } \\
\text { modified crutches for } \\
8 \text { metres continuously } \\
9 \text { - } 12 \text { months walked on } \\
\text { smaller modified crutches } \\
\text { for } 8 \text { metres continuously }\end{array}$ & 5 \\
\hline Other exercises & $\begin{array}{l}\text { Crawling, upper body cycling, } \\
\text { weight training, core stability } \\
\text { and mat exercises }\end{array}$ & Same & Same & 5 \\
\hline \multicolumn{5}{|l|}{ Other therapies } \\
\hline Reflexology & $1 \mathrm{x}$ week & & & \\
\hline Acupuncture & $1 \mathrm{x}$ week & & & \\
\hline Podiatry & $1 \mathrm{x}$ week & $1 \mathrm{x}$ week & & \\
\hline Massage & $1 \mathrm{x}$ week & $1 \mathrm{x}$ week & - & - \\
\hline Hydrotherapy & $1 \mathrm{x}$ week & $1 \mathrm{x}$ week & - & - \\
\hline $\begin{array}{l}\text { Transcutaneous } \\
\text { electro-muscular } \\
\text { stimulation }\end{array}$ & $\begin{array}{l}\text { Rectus abdominus, } \\
\text { rectus femoris: } 3 x \text { half hour } \\
\text { per day }\end{array}$ & - & - & - \\
\hline
\end{tabular}

A further challenge to this kind of therapy is the physical strain therapists are subjected to. Two therapists sit on the side of the treadmill and manually lift the patient's limbs. The limbs are lifted at the end of stance phase and then propelled forward and placed down in heel strike. This action tends to place strain on the lower back. There have been some recent developments in robotic assistive devices which take the place of the therapists, ${ }^{7}$ but they are very costly.

In conclusion, locomotor therapy formed part of a regimen that resulted in the patient being able to walk with modified crutches. This level of movement transferred into the patient being able to perform more activities of daily living. Future challenges to improved patient care are randomised multi-centre controlled trials designed to test the efficacy of duration, frequency and intensity of this type of training on the multiple classifications of spinal cord injuries. Furthermore, from a technology perspective, robotic assistive devices that can aid therapy for patients with spinal cord injuries should be developed.

\section{REFERENCES}

1. Barbeau $\mathrm{H}$ and Rossignol $\mathrm{S}$. Recovery of locomotion after chronic spinalization in the adult cat. Brain Res 1987; 412: 84-95.

2. Behrman AL, Bowden MG, Nair PM. Neuroplasticity after spinal cord injury and training: An emerging paradigm shift in rehabilitation and walking recovery. Phys Ther 2006; 86: 1406-25.

3. Buerger AA, Fennessy A. Long-term alteration of leg position due to shock avoidance by spinal rats. Exp Neurol 1971; 30: 195-211.

4. Dietz V, Colombo G, Jensen L, Baumgartner L. Locomotor capacity of spinal cord in paraplegic patients. Ann Neurol 1995; 37: 574-82.

5. Dietz V, Harkema SJ. Locomotor activity in spinal cord-injured persons. $J$ Appl Physiol 2004; 96: 1954-60.

6. Dobkin B, Apple D, Barbeau H, Basso M, Behrman A, Deforge D. Weightsupported treadmill vs overground training for walking after acute incomplete SCI. Neurology 2006; 66: 484-93.

7. Hornby TG, Zemon DH, Campbell D. Robotic-assisted, body-weight supported treadmill training in individuals following motor incomplete spinal cord injury. Phys Ther 2005; 85: 52-66.

8. Lovely RG, Gregor RJ, Roy RR, Edgerton VR. Effects of training on the recovery of full-weight-bearing stepping in the adult spinal cat. Exp Neurol 1986; 92: 421-35.

9. Wernig A, Nanassy A, Muller S. Laufband (treadmill) therapy in incomplete paraplegia and tetraplegia. J Neurotrauma 1999; 16: 7197-26. 